\title{
PANENTEISME DALAM PEMIKIRAN TEOLOGI METAFISIK MOH. IQBAL
}

\author{
Suhermanto Ja'far \\ IAIN Sunan Ampel Surabaya \\ herman_jafar@gmail.com
}

\begin{abstract}
Abstrak
Panenteisme merupakan salah satu paham tentang Tuhan yang meyakini bahwa alam adalah bagian dari Tuhan. Secara geneologi paham panenteisme merupakan pengembangan idealisme Jerman pada abad ke-19, khususnya pada karya Fichte, Hegel, Schelling, dan dilanjutkan oleh Alfred North Whitehead pada abad 20. Begitu populernya gagasan Panenteisme ini hingga cukup berpengaruh pada pemikiran teologis Iqbal. Tulisan ini membahas tentang paham Panenteisme dalam pemikiran teologi metafisik M. Iqbal. Dalam hal ini Iqbal lebih mengarah pada eksistensi Realitas absolut, sebagai realitas yang sebenarnya dalam hubungannya dengan manusia dan alam. Karena itu, Realitas Ultim, Realitas Diri, Wujud Mutlak atau Ego Mutlak hanya dapat dicapai dengan intuisi. Untuk sampai mengetahui dan memahami Wujud Mutlak, Iqbal bertitik tolak dari intuisi tentang wujud ego manusia yang bergerak pada Realitas Wujud Ego Mutlak. Hanya intuisi, kata Iqbal yang dapat mengungkap Realitas Mutlak atau Wujud Super Ego yang sebenarnya. Hal ini karena kodrat Realitas yang sesungguhnya adalah spiritual.
\end{abstract}

\section{Abstract}

PANENTHEISM IN THINKING THEOLOGY METAPHYSICAL MOH. IQBAL. Panentheism is a kind of understandings of God who believes that nature is a part of God. Genealogcally, panentheism is an elaboration of German idealism in the 19th century, especially in the work of Fichte, Hegel, Schelling, and followed by Alfred North Whitehead in the 20th century. So popular the idea is that it influences theological thinking of Iqbal. This paper discusses Panentheistic understandings in the metaphysical theology of M. Iqbal. In this case Iqbal more leads to the existence of absolute reality, a reality that is true in relation to man and nature. Therefore, Ultimate 
Reality, Reality Self, Absolute Being or the Absolute Ego can only be achieved by intuition. To get to know and understand the Absolute Being, Iqbal starts from the intuition of the nature of human ego moving on Being Ego Absolute Reality. Only intuition, said Iqbal, which can reveal the Absolute Reality or actual realization of the Super Ego. This is because the true nature of reality is spiritual.

Kata Kunci: Iqbal; panenteisme; realitas; intuisi, teologi; metafisik.

\section{A. Pendahuluan}

Panenteisme adalah suatu bentuk teisme yang berkeyakinan bahwa alam adalah bagian dari tuhan, tapi tuhan tidaklah identik dengan alam. Pandangan ini diikuti oleh teologi proses dan juga Hindu. Menurut Hindu, alam adalah bagian dari Tuhan, tetapi Tuhan tidak sama dengan alam melainkan mentransendensikannya. Akan tetapi, berbeda dengan teologi proses, "Tuhan dalam Hinduisme itu Mahakuasa. Panenteisme dipahami sebagai Tuhan ada di dalam alam sebagaimana jiwa berada di dalam tubuh". Dengan penjelasan yang sama, panenteisme juga disebut teisme monistik di dalam Hinduisme. Namun karena teologi proses juga tercakup di dalam definisi yang luas dari panenteisme dan tidak menerima kehadiran Yang Mahatinggi dan Yang Mahakuasa, pandangan Hindu dapat disebut sebagai teisme yang monistik. ${ }^{1}$

Seperti dijelaskan sebelumnya, bahwa istilah panentheism tampaknya telah digunakan pertama kali oleh Karl Friedrich Christian Krause (1781-1832), walaupun aspek pembahasan tersebut sudah ada sejak Plato. Pengenalan lebih lanjut kepercayaan panentheistic dapat ditemukan dalam pengembangan idealisme Jerman pada abad ke-19, khususnya dalam karya Fichte, Hegel, dan Schelling, dan dalam pengembangan theisme pada abad ke 20, misalnya dalam karya Alfred North Whitehead. ${ }^{2}$ Kurang lengkap kiranya jika kita tidak banyak mengetahui pemikiran-pemikiran Whitehead tentang Tuhan dan panenteisme, karena gagasan

${ }^{1}$ Whittemore, Robert C., 1988, "The meeting of East and West in neglected Vedanta”, Dialogue \& Alliance, h. 2, 33-47.

${ }^{2}$ Whittemore, Robert C., 1960, "Hegel As Panenteis", Studies in Hegel, Series: Tulane Studies in Philosophy, Volume 9, 1960, h. 134-164. 
panenteisme bisa popular dan menjadi sistem teologis maupun filosofis berkat sumbangan pemikirannya, melalui filsafat proses maupun teologi prosesnya.

\section{B. Iqbal dan Panenteisme}

Iqbal merupakan seorang pemikir agung dari negeri Timur dilahirkan dari keluarga menengah. Sekalipun Iqbal berasal dari keturunan Brahmana, ${ }^{3}$ namun ia datang dari keluarga miskin. Ia lahir pada tanggal 22 Pebruari 1873 di Chungaran Bazaar yang kita kenal dengan nama Iqbal Bazaar, di kota Sialkot Propinsi Punjab Barat. ${ }^{4}$ Ayahnya, pada mulanya bekerja pada dinas pemerintahan, dan kemudian beralih ke pedagang, adalah seorang amat saleh dan kuat beragama. ${ }^{5}$ Iqbal menerima pendidikan permulaan di sebuah Maktab. Kemudian setelah menyelesaikan pendidikan di Sialkot, ia meneruskan pelajarannya ke ibukota provinsi di Lahore tahun 1895.

Atas dorongan Thomas Arnold, pada tahun 1905 Iqbal meneruskan studinya di Eropa, pertama-tama ke Inggris masuk ke Universitas Cambridge untuk mempelajari filsafat di bawah bimbingan Mac. Taggart. Pada saat yang sama ia juga mengikuti kuliah-kuliah Hukum di Lincoln's Inn London. Akhirnya ia berhasil mendapatkan gelar sarjana Hukum Inggris. Dua tahun kemudian ia

${ }^{3}$ Al-Biruni, Maker's of Pakistan and Modern Muslim India, (Lahore: Kasymir Bazar, 1950), 169. Nenek moyang Iqbal berasal dari Kashmir. Keluarga Iqbal keturunan Breahmana yang ahli dalam ilmu mistik dari Rum dan Tabriz"' Lihat dalam Schimel, Gabriel's Wing: A Study into Religion of Sir Muhammad Iqbal (Leiden : E.L. Brill, 1963), h. 35.

${ }^{4}$ Ada sedikit perbedaan mengenai tahun kelahiran Iqbal, W.C. Smith menyebutkan bahwa kelahiran Iqbal tahun 1876, tapi Smith dalam catatan kaki menyebutkan bahwa tahun 1873 adalah yang paling banyak diyakini. Adapun tanggal 22 Pebruari tahun 1873 adalah hasil penelitian S.A. Vahid dalam bukunya Iqbal, His Art and Thought. Berdasarkan catatan Hafess Malik dan Lynda H.L.M, Danusuri menjelaskan bahwa tanggal kelahiran Iqbal adalah tanggal 9 Novemper 1877, akan tetapi Iqbal sendiri mengaku bahwa tanggal kelahiranya adalah 2 Dzul al-Qa'dah 1294. Lihat Danusuri, Epistimologi Dalam Tasawuf Iqbal (Yogyakarta: Pustaka Pelajar, 1996), h. 3.

${ }^{5}$ Smith, Wilfred Contwell, Modern Islam in India, A Social Analysis, Usha Publication, (New Delhi, 1979), h. 116-117; Lihat Ali Audah, Muhammad Iqbal, Sebuah Pengantar dalam Muhammad Iqbal, Membangun Kembali Pikiran Agama Dalam Islam, terj. Ali Audah, (Jakarta: Tintamas,1982), h. x. 
pindah ke Munich di Jerman, dan disinilah ia memperoleh gelar $\mathrm{Ph}$. D. dalam tasawuf. Tesis doktoral yang dimajukannya berjudul The Development of Metaphysics in Persia. ${ }^{6}$

Selama tiga tahun belajar di Inggris dan Jerman, sikap Iqbal dalam banyak hal mengalami perubahan besar, ia pergi ke Inggris sebagai seorang nasionalis dan panteis, tetapi kembali ke India sebagai Pan-Islamis dan hampir-hampir saja puritan (pemurni). Demikian Iqbal, pada tahun 1908 ia kembali ke Lahore, ${ }^{7}$ dan disamping pekerjaannya sebagai pengacara ia menjadi dosen filsafat. Bukunya The Recontruction of Religious Thought in Islam adalah hasil ceramah-ceramah yang diberikannya di beberapa univesitas di India. Saat-saat sulit yang dihadapi umat Islam India di penghujung tahun 1920-an, memaksa Iqbal memasuki gelanggang politik. Tahun 1927, ia terpilih sebagai anggota Dewan Legeslatif Punjab. Pada saat yang sama, dia juga terpilih menjadi sekretaris Liga Muslim. Sekalipun demikian, dunia tulis-menulis tetap menjadi aktifitas utama yang tak pernah ditinggalkan. ${ }^{8}$ Iqbal meninggal dalam suasana tenang dengan senyum mengembang di bibir pada tahun 1938 M. Jenazah Muhammad Iqbal dimakamkan dekat pintu gerbang Masjid Shahi di Lahore. Setengah jam sebelum menghembuskan nafas terakhir, masih sempat ia membisikkan sajak yang terkenal:

Melodi perpisahan boleh menggema atau tidak

Bunyi nafiri boleh bertiup lagi dari Hijaz atau tidak

Saat si Fakir telah sampai ke Batas terakhir

Pujangga lain boleh datang atau tidak

Kata terakhir sekali yang terucapkan oleh Iqbal ialah "Allah" . Ia hidup di tangan Tuhan, dan mati di tangan Tuhan. Ketika itulah, saat fajar mulai terbit tanggal 21 April $1938,{ }^{10}$ menyinari kota Lahore, dunia kehilangan seorang pujangga dan filsuf besar.

Pemikiran ontologi Iqbal lebih mengarah pada eksistensi Realitas absolut, sebagai realitas yang sebenarnya dalam

${ }^{6}$ Harun Nasution, Pembaharuan...,h. 190.

${ }^{7}$ Ibid., h. 118.

${ }^{8}$ Albiruni, Maker's..., h. 177.

${ }^{9}$ Ali Audah, Mohammad Iqbal..., h. xxxvi (sajak dikutip dari S.A. Vahid)

${ }^{10} \mathrm{Ibid}$., h. xxxvii, H.A. Mukti Ali menyebut wafat Iqbal tanggal 18 Maret 
hubungannya dengan manusia dan alam. Karena itu, Realitas Ultim, Realitas Diri, Wujud Mutlak atau Ego Mutlak hanya dapat dicapai dengan intuisi. Untuk sampai mengetahui dan memahami Wujud Mutlak, Iqbal bertitik tolak dari intuisi tentang wujud ego manusia yang bergerak pada Realitas Wujud Ego Mutlak. Hanya intuisi, kata Iqbal yang dapat mengungkap Realitas Mutlak atau Wujud Super Ego yang sebenarnya. Hal ini karena kodrat Realitas yang sesungguhnya adalah spiritual. ${ }^{11}$

Realitas yang ada menurut Iqbal merujuk pada Wujud Tuhan, Manusia dan alam, tetapi realitas yang ada dan sebenarnya ada adalah wujud dari Realitas absolut, Wujud absolut atau Ego Mutlak. Dengan demikian, Realitas absolut, Wujud absolut atau Ego Mutlak merupakan realitas yang eksistensi wujudnya pasti ada dan tidak mungkin tidak ada. Sesungguhnya, Realitas Absolut atau Ego Mutlak merupakan keseluruhan dari hakikat dan realitas. ${ }^{12}$ Realitas Mutlak atau wujud Super Ego juga mengandung didalamnya egoego terbatas dalam wujudnya, tanpa menghapus eksistensi ego-ego terbatas. Di sinilah, kata Iqbal relasi antara Realitas Mutlak atau wujud Super Ego dengan ego-ego terbatas yang sesungguhnya. ${ }^{13}$

Eksistensi Realitas yang sebenarnya adalah wujud Ego yang tidak bergantung kepada non Ego, sehingga menyebabkan terjadinya ketegangan antara Ego Absolut atau Wujud Mutlak dengan bukan wujud Ego. Pada akhirnya, Wujud Ego Absolut, kata Iqbal dapat memberi pada semua dunia atau Semua ada dalam Tuhan. Berkaitan dengan ketegangan tersebut, sesungguhnya bukan ego tersebut

\footnotetext{
${ }^{11}$ Iqbal, The Recontruction of Religious Thought in Islam (New Delhi: Kitab Bhavan, 1981), h. 38-39.

${ }^{12} \mathrm{Ibid}$, h. 54.

${ }^{13}$ Menurut Iqbal ada tiga cara relasi wujud Mutlak atau Ego absolut dengan ego-ego terbatas yang dapat dideskripsikan Pertama, Realitas Mutlak, Wujud Absolut atau Super Ego adalah satu-satunya realitas, ia menyerap dalam wujudnya ego-ego terbatas yang tidak mempunyai eksistensi. Kedua, Realitas Mutlak, wujud Absolut atau Super Ego merangkum ego-ego terbatas dalam wujudnya tanpa menghapus eksistensi mereka. Ketiga, Realitas Mutlak, Wujud Absolut atau super Ego dianggap sebagai lepas dan berada di atas ego-ego terbatas. Untuk kasus yang ketiga ini, Iqbal secara tegas menolak. Ini dianggap bahwa antara Wujud Mutlak yang tak terbatas terdapat jurang dengan ego-ego terbatas. Begitu pula dengan pandangan yang pertama dianggap juga ditolak Iqbal, karena melalui intuisi diri, ego justru semakin menampakkan eksistensinya. Lihat, Miss Luce-Claude Maitre, pengantar..., h. 54-55.
} 
merupakan sebuah waktu yang berlalu dalam realitas Absolut. Sekalipun waktu hadir pada Tuhan, namun ke-Ego-an Realitas Absolut bersifat mandiri dan absolut. Realitas Mutlak, Wujud Ego Absolut bersifat kreatif, sehingga segala sesuatu yang bukan Realitas Mutlak, Wujud Ego absolut akan mampu berkembang dan akibatnya tidak ada batasnya. Ketidak terbatasan Realitas Mutlak, wujud Ego Absolut lebih bersifat potensial daripada aktual. Untuk itu, momen atau waktu merupakan elemen mendasar dalam realitas absolut. ${ }^{14}$ Realitas Mutlak sebagai Ego oleh al-Qur'an disebut dengan nama Allah menurut Iqbal. ${ }^{15}$

Konsep teologi metafisika Iqbal tentang Tuhan dan pemikiran filosofisnya secara umum, sesungguhnya mengalami pasang surut, mulai dari pola panteistik sebagaimana para mistikus, menjadi rasional sebagaimana para filosof Barat sampai pola intuisi sebagaimana para sufi. Ini dapat kita lihat dari perkembangan dan pengembaraan intelektual Iqbal dalam memahami Tuhan selama di India (Pakistan), ketika di Eropa (bersentuhan dengan filsof Barat) dan sekembalinya dari Eropa.

Ide-ide Iqbal tentang pemikiran filsafatnya, termasuk tentang teologi metafisikanya mengalami perkembangan yang menarik. Teologi metafisika Iqbal dan pemikirannya tentang Tuhan mengalami perubahan tiga tahap, yaitu: tahap Pertama (1901-1908), suatu tahapan pemikiran Iqbal yang masih berada di India. Pada tahap ini, Iqbal meyakini Tuhan sebagai Keindahan Abadi, yang ada-Nya tanpa tergantung pada sesuatu. Tuhan menurut Iqbal masih bersifat tajalli, yaitu Tuhan menampakan diri-Nya pada segala sesuatu. Tuhan menyatakan diriNya pada alam semesta dan makhluk-Nya. Tuhan menyatakan diriNya pada Bumi, langit, matahari, bintang, bulan maupun makhluk hidup lainnya.

Pada tahap ini, Tuhan menurut Iqbal sebagai Keindahan Abadi adalah penyebab adanya gerak segala sesuatu. Tuhan sebagai Keindahan Abadi adalah sumber, esensi dan ideal dari segala sesuatu. Tuhan bersifat universal dan melingkupi segalanya. Tuhan oleh Iqbal diibaratkan sebagai matahari, sedangkan individu manusia ibarat seperti lilin dan nyala lilin lenyap di tengah cahaya. Pada

\footnotetext{
${ }^{14}$ Iqbal, Reconstruction..., h. 54-57.

${ }^{15} \mathrm{Ibid}$, h. 64-65 dan 71-73.
} 
tahapan ini, pemikiran Tuhan Iqbal masih cenderung panteistik, sebagaimana konsep para mistikus yang kemudian hari pandangan ini dikritiknya.

Intuisi bukan properti rasio yang mana rasio hanya menangkap fenomena: aspek realitas sebagaimana tampak melalui persepsi inderawi. Hati menurut Iqbal membawa manusia kepada kontak langsung dengan realitas yang tidak terbuka bagi persepsi inderawi. ${ }^{16}$ Apabila rasio menangkap realitas dalam kategorikategori (substansi, kausalitas, modalitas) maka hati menangkap realitas secara esensial - utuh.

Tahap kedua (1908-1920) merupakan tahap pemikiran Iqbal yang bersifat rasional filosofis, setelah berkenalan dengan pemikiran Barat. Tahap ini merupakan tahap pemikiran Iqbal yang mengalami perubahan yang cukup signifikan mengenai keindahan. Iqbal menganggap keindahan sebagai sesuatu yang kekal, sedangkan kausalitas sebagai akhir dari cinta, gerakan dan keinginan. Pandangan ini oleh Iqbal diredefinisi, karena Iqbal pada tahap ini mengalami kesangsian dan pesimisme tentang sifat kekal dari keindahan. Semua ini tampak pada syair-syair Iqbal mengenai Jalwahi al-Husn (Visi keindahan), Haqāqati al-Husn (Hakikat keindahan), Șabnam aur Sitare (embun-embun dan bintang-bintang sebagai ekspresi dari perubahan sikap Iqbal.

Bersamaan dengan sikap pesimisme dan kesangsian ini, tumbuhlah dalam diri Iqbal suatu keyakinan akan keabadian tentang cinta, hasrat dan gerak. Iqbal merumuskan keyakinannya ini dalam puisi-pusinya yang baru seperti; Bang-I Dara, Asrar-I Khudi dan Rumuz-i Bekhudi. Pemikiran Iqbal tentang Tuhan dibimbing oleh konsep tentang pribadi (self, Khudi) yang dianggap sebagai pusat dari cinta. Begitu pula Tuhan menurut Iqbal merupakan Pribadi Mutlak (Ego absolut). Konsep pribadi (khudi) menurut Iqbal merupakan gerak yang merambah dengan menaklukan kesulitan halangan

${ }^{16}$ Iqbal mengadopsi konsep hati dari sufi besar Jalaludin Rumi yang mengatakan bahwa hati adalah semacam intuisi yang menyerap cahaya super sensuous sun dan membawa kita pada kontak langsung dengan aspek realitas yang tertutup bagi persepsi inderawi maupun nalar manusia. Untuk lebih jelasnya lihat, M.M. Sharif, History of Muslim Philosophy, (Pakistan: Pakistan Philosophical Congress, 1983), h. 1625. 
dan rintangan. Menurut Iqbal Pribadi (khudi) tidak maujud (non eksistensi) dalam waktu, tetapi waktulah yang merupakan gerak dari pribadi. Waktu sebagai aksi, gerak adalah kehidupan itu sendiri. Kehidupan itu sendiri adalah pribadi. Pribadi menurut Iqbal untuk mewujudkan eksistensinya menuntut dari dirinya sendiri yang bukan pribadi. Demi untuk kesempurnaannya sendiri. Karena itu, pribadi akan selalu bergerak menjadi (becoming).

Pada tahap ini, Iqbal menganggap Tuhan tidak lagi sebagai keindahan luar saja, melainkan menganggap keindahan sebagai sifat dari Tuhan itu sendiri.Tuhan menampakan darinya bukan dalam dunia yang terindera, melainkan pada pribadi yang terbatas. Tuhan hanya bisa didekati melalui pribadi, bukan dengan memintaminta, tetapi dengan ketinggian martabat pribadi. Manusia dalam mencari Tuhan, kata Iqbal harus berangkat dari kemauan dan kekuatannya sendiri.

Dengan menemukan Tuhan, manusia tidak boleh membiarkan dirinya terserap ke dalam Tuhan dan menjadi tiada. Sebaliknya, manusia harus menyerap Tuhan ke dalam dirinya. Menurut Iqbal, dengan menyerap Tuhan ke dalam dirinya secara terus menerus, maka tumbuhlah ego. Ketika Ego menjadi Superego, manusia sebagai pribadi naik pada tingkatan wakil Tuhan. Inilah nantinya yang menjadi sentral pemikiran Iqbal tentang manusia sempurna (Insan Kamil).

Pada tahapan ini, Iqbal memandang Tuhan telah sangat rasional, sekalipun intuisi masih mendominasi. Pengaruh Bergson khususnya tentang intuisi membuat konsep intuisi Iqbal bergeser dari konsep intuisi para mistikus. Iqbal juga menolak kaum mistikus yang bertolak dari pemahaman tentang realitas ultim dan kemudian mengklaim intuisi sebagai fakultas yang bisa membawa manusia kepada pengetahuan tentangNya. Iqbal, sebaliknya, bertolak dari pengetahuan intuitif yang bisa kita ketahui langsung dalam kehidupan sehari-hari yakni pengetahuan intuitif tentang adanya diri (self).

Iqbal mengatakan bahwa intuisi tentang diri jauh lebih kuat dan tak dapat diragukan daripada intuisi tentang realitas ultimate. Iqbal berbeda dengan para mistikus bertolak dari intuisi tentang diri dan baru kemudian beranjak ke intuisi tentang realitas 
ultim. Intuisi tentang adanya diri-lah yang membawa manusia pada intuisi tentang realitas ultim. Pemikiran Iqbal tentang intuisi sebagai pengetahuan mengenal dan memahami diri, sehingga dari pemahamn diri ini meningkat pada pemahaman tentang realitas absolut, yaitu Tuhan. ${ }^{17}$

Tahap Ketiga (1920-1938) sampai tahun meninggalnya Iqbal. Pada tahap ini, pemikiran Iqbal semakin menampakkan kecemerlangannya sebagai seorang pemikir (filosof), penyair maupun sebagai sastrawan. Jika pada tahap kedua, pemikiran Iqbal dapat dianggap sebagai tahap pertumbuhan, maka tahap ketiga ini dapat dianggap sebagai tahap kedewasaan. Pemikiran filsafat Iqbal pada tahap ini dapat dikatakan sebagai filsafat perubahan yang berdasarkan pada gerak.

Ide tentang hakikat pribadi masih menonjol, tetapi filsafat tentang gerak dan perubahannya lebih menonjol lagi. Pada Tahap ini, Tuhan menurut Iqbal adalah hakikat keseluruhan yang bersifat spiritual. Dengan kata lain, Tuhan bukanlah ego, melainkan Ego Mutlak. Tuhan bersifat mutlak, karena meliputi segalanya dan tidak ada sesuatupun di luar Dia. ${ }^{18} \quad$ Pada akhir-akhir menjelang kematiannya, Iqbal semakin menampakkan pemikirannya yang orisinal mengenai Tuhan sebagai hakikat keseluruhan dari segala kreativitas, karena Tuhan sendiri selalu kreatif memberikan ilham tentang filsafat perubahan, tindakan, aksi yang lebih dikenal dengan istilah Islam adalah amal. Di sinilah letak sintesa filosofi Iqbal dari Barat maupun Timur (Islam) dengan pemikirannya yang orisinil. Sekalipun sesungguhnya, konsep tentang gerak hubungan dengan Tuhan telah dimulai dari Aristoteles. ${ }^{19}$

${ }^{17}$ Pandangan Iqbal di atas mengenai intuisi sebagai media pengenalan kepada diri merupakan faktor urgen dalam mengenal realitas Ultim merupakan pandangan para kaum sufi. Lihat Ishrat Hasan Enver, Metaphisics of Iqbal, (Lahore: Ashraf Press, 1963), h. 8.

${ }^{18}$ Untuk lebih jelasnya mengenai tahapan-tahapan pemikiran Iqbal tentang hal tersebut dapat kita lihat pada tulisan Iqbal, Mc. Taggart's Philosophy, dalam Journal of the East India Society, (1917) Lahore.

${ }^{19}$ Tentang ajaran gerak, Aristoteles sampailah kepada pemahaman adanya penggerak pertama dan penggerak kedua. Penggerak pertama terjadi dengan sendirinya, tanpa melalui perantara kekuatan lain. Sementara penggerak kedua terjadi karena kekuatan penggerak pertama. Penggerak ini merupakan "penggerak yang tidak digerakkan”, yakni Allah. Penggerak pertama yang sedemikian itu tidak 
Dalam puisi, prosa maupun esainya, Iqbal kerap berbicara tentang “ ke-diri-an Tuhan" dan menjelaskan Tuhan sebagai Ego mutlak. Bagi Iqbal, nama Allah itu sendiri, sebagaimana Tuhan sendiri memanggil diri-Nya dalam al-Qur'an, merupakan gambaran karakter personalitas-Nya. Untuk menekankan karakter individualitas Ego mutlak ini, al-Qur'an (lihat surat al-Ikhlas) menyebut-Nya dengan Allah dan membatasinya bahwa Dia adalah Esa; segalanya tergantung kepada-Nya; Ia tidak beranak dan tidak pula diperanakan; dan tidak ada satupun yang menyamai-Nya. Surat tersebut menurut Iqbal adalah bukti yang tegas dari individualitas Tuhan, Sang Ego Yang Mutlak. ${ }^{20}$ Iqbal memandang secara seimbang bahwa pengalaman panteistik manusia dengan Tuhan tidak membuat lebur ego manusia, justru ego manusia semakin otentik. Filsafat ketuhanan Iqbal di sini justru lebih memperkuat eksistensi ego manusia, sehingga pemikirannya lebih bersifat panenteisme. Panenteisme merupakan konsep ketuhanan yang menitik beratkan pada semua di dalam Tuhan, bukan semua adalah Tuhan sebagaimana panteisme. $^{21}$

Dalam tulisan-tulisanya, Iqbal memang banyak menyerang tasawuf yang panteistik. Tasawuf panteistik disamping efeknya yang melemahkan, dalam pandangan Iqbal juga barang asing yang tidak memiliki akarnya dalam ajaran Islam. Tasawuf panteistik adalah perkembangan belakangan yang merupakan cangkokan dari metafisika Persia dan Yunani. Dalam bukunya, The Development of Metaphysics in Persia, dia menulis bahwa pengaruh hubungan kehidupan dan persilangan gagasan di Persia menciptakan hasrat pada orang-orang tertentu untuk mewujudkan suatu pernyataan baru mengenai Islam dengan mengasimilasi gagasan Kristen dan spekulasi Gnostik Kristen. Menurut Iqbal, munculnya tasawuf panteisme dalam Islam bisa dijelaskan dengan memotret kondisi

berasal dari alam dunia, sebab di dalam jagad raya ini tiap gerak digerakkan oleh yang lain. Penggerak ini adalah Allah. Ialah yang menyebabkan gerak abadi, yang Ia sendiri tidak digerakkan. Allah adalah actus purus, pemikiran murni. John Rowe Workman (ed.), Encyclopedia Americana, 2 (Encyclopedia Americana Coorporation, 1978), h. 288.

${ }^{20}$ Iqbal, The Recontruction..., h. 62.

${ }^{21}$ Charles Hartshorne dan William Reese, Philosophers speak of God, (ChicagoLondon : The University of Chicago Press, 1976), h. 294-297. 
dan pikiran Persia yang hampir-hampir bersifat bawaan memiliki kecenderungan ke arah monisme. ${ }^{22}$

Di dalam tasawuf Islam, sebutan panteisme biasanya ditujukan pada konsep Wiḥdah al-Wujūd yang dikembangkan Ibn al-Arabi (1240 M). Dalam hal ini Iqbal sendiri dalam seranganseranganya terhadap tasawuf panteistik juga tertuju pada konsep ini. Dalam salah satu suratnya, dia mengatakan bahwa" sejauh yang saya ketahui, kitab Fușuṣ (Fuṣūṣ al-Ḥikām karya Ibn 'Arabi) tidak berisikan apapun kecuali ateisme dan bid'ah. ${ }^{23}$ Karena menurut Ibn 'Arabi, satu-satunya wujud adalah Tuhan. Segala sesuatu selain Dia adalah "'adam". Kalaupun yang terakhir itu tetap disebut wujud, penyebutan itu hanya bersifat metaforis karena semua wujud sesungguhnya hanya milik Tuhan. Konsep sentral dalam Wiḥdah alWujū adalah Tajalli. Tajalli adalah proses penampakan diri al-Haqq yang tidak dikenal secara absolut menjadi bentuk-bentuk kongkrit. Tajalli adalah penampakan diri Tuhan dalam bentuk-bentuk yang tidak terbatas di alam semesta.

Tuhan dianggap sebagai Ego karena Dia merupakan prinsip kesatuan yang mengorganisir. Suatu paduan yang terikat satu sama lain yang berpangkal pada fitrah kehidupan organisme-Nya untuk suatu tujuan konstruktif. ${ }^{24}$ Tujuan di sini tidak dalam arti titik batas bagi kreatifitas Tuhan, yang hal ini berarti menunjukkan ketidaksempurnan-Nya.MasadepanbagiTuhanadalahkemungkinan yang terbuka, bukan suatu susunan peristiwa yang telah ditetapkan dengan garis yang jelas. Karena itu pula, kemahatahuan Tuhan, menurut Iqbal bukanlah pengetahuan diskursif, suatu proses temporal yang bergerak di sekeliling "yang lain", yang secara per se berhadap-hadapan dengan ego yang mengetahui. ${ }^{25}$ Dalam pandangan Vahiduddin, Iqbal tidak dapat menghindar dari mata

${ }^{22}$ Muhammad Iqbal, Metafisika Persia: Suatu Sumbangan untuk Sejarah Filsafat Islam, terj. Joebaar Ayoeb (Bandung: Mizan, 1995), h. 87. Monisme memandang bahwa segala sesuatu adalah dzat Yang Satu. Dalam pengertian ini segala sesuatu yang ia alami hanyalah sebuah illusi karena segala sesuatu yang terlihat oleh kita pada hakekatnya adalah satu.

${ }^{23}$ Manzhoor Ahmad, Metafisika Persia dan Iqbal, dalam Muhammad Iqbal, Metafisika Persia..., h. 13.

${ }^{24} \mathrm{Ibid}$, h. 40

${ }^{25}$ Iqbal, The Recontruction..., h. 77. 
rantai panteistik ketika dia menyatakan bahwa dunia seluruhnya adalah penampakan diri dari Aku Yang Benar. Jadi, menurut Vahiduddin, sekalipun Iqbal memakai metafor cahaya terhadap konsep Tuhan lebih sebagai keabsolutan-Nya, bukan kehadiran-Nya, tetapi dengan menyatakan bahwa Ego Mutlak adalah keseluruhan realitas, maka hal itu menunjukkan bahwa Tuhan hadir dalam keseluruhan level realitas. Dan ini kurang lebih karakter pikiran panteistik. ${ }^{26}$

Akan tetapi Iqbal sendiri menyatakan bahwa kodrat ego adalah terpusat pada dirinya sendiri sekalipun ia memiliki kemampuan untuk berhubungan dengan ego-ego lain. Keluasan Ego mutlak bukanlah keluasan ekstensitas, melainkan intensitas sehingga sekalipun ego terbatas tidak terpisah dengan Ego mutlak, tetapi ia tetap berbeda. ${ }^{27}$ Pendapat Iqbal yang lebih menekankan terhadap transendensi Tuhan juga bisa dilihat tekanannya pada keesaan Tuhan. Bagi Iqbal, kesempurnaan individualitas memerlukan suatu keadaan ketunggalan mutlak. Individu yang sempurna tidak boleh meletakkan sekutu dalam dirinya sendiri. Sifat Ego sempurna ini adalah unsur yang paling esensial dalam konsepsi al-Qur'an tentang Tuhan. ${ }^{28}$

Di samping menggambarkan Tuhan sebagai Ego, Iqbal juga mengkaitkan konsep ketuhanannya dengan kekuatan (power). ${ }^{29}$ Seperti yang telah disinggung di awal bahwa konsep ketuhanan Iqbal lebih bersifat eksistensial. Uraian Iqbal tentang Tuhan pertama-tama tidak menghadirkan konsep tentang, melainkan cara bagaimana hidup seseorang mempunyai sifat ke-Ilahi-an. Tuhan yang digambarkan sebagai kekuatan adalah pilihan sadar seseorang yang berangkat dari kesadaran eksistensialnya. Tidak lagi menjadi persoalan bagi Iqbal bahwa di samping Maha kuat, Tuhan juga Maha Kasih, karena pada akhirnya manusialah yang mengkonsepsi kesiapan Tuhan, sementara hakekat Tuhan tetap berada di luar jaring intelek manusia. Dan ketika kesadaran eksistensialnya

${ }^{26}$ Syed Vahiduddin, Islam in India: Studies and Commentaris, Vol 3 (New Delhi: Chanakya Publition, tt), h. 159.

${ }^{27}$ Iqbal, The Recontruction..., h. 118.

${ }^{28}$ Ibid, h. 62.

${ }^{29}$ Fauzi dan Agustina, Sisi Manusiawi Iqbal..., h. 106. 
dibangun di atas pondasi kekuatan (power), maka dengan demikian, Tuhan lebih baik digambarkan sebagai kekuatan. Dalam pengertian inilah Iqbal secara lantang menyatakan bahwa kekuatan (ke-Maha Kuasaan) itu lebih dekat pada sifat ke-Ilahi-an Tuhan. Bagi Iqbal, keilahian adalah powerfullness.

Dengan menggambarkan Tuhan sebagai kekuatan, maka kekuatan akan muncul dalam diri manusia. Dan ketika kekuatan telah lahir dalam diri orang-orang muslim, maka semangat Islam yang sesungguhnya akan terlahir kembali. Semangat yang telah mampu menciptakan peradaban yang gemilang, semangat yang telah mampu menarik orang-orang Eropa untuk belajar ke Baghdad di abad pertengahan."Peradaban adalah hasil pikiran orang yang kuat, orang yang kuat menciptakan lingkungan, orang yang lemah harus menyesuikan diri dengan lingkungan,"kata Iqbal. ${ }^{30}$

Dengan demikian, gagasan Iqbal tentang Tuhan sebagai Ego dan kekuatan, tidak lain adalah proyeksi gagasannya tentang manusia sempurna, yaitu manusia yang memiliki ego yang sangat unik dan kuat, serta pada saat-saat yang sama adalah manusia yang mampu menyerap kebaikan-kebaikan Tuhan ke dalam dirinya. Jadi relasi Tuhan-manusia di sini tidak bergerak dari Tuhan ke manusia, tetapi sebaliknya dari manusia pada Tuhan.

Pemikiran Iqbal tentang alam semesta tidak terlepas dari pemikirannya tentang Tuhan dan Diri manusia. Karena itu, sesungguhnya alam semesta bagi Iqbal merupakan salah satu sarana pembahasan dalam hubungannya dengan adanya Tuhan dan manusia, sehingga ketiganya merupakan satu kesatuan yang utuh dalam pemikiran Iqbal. Iqbal memandang alam semesta bukanlah satu kumpulan benda-benda yang menempati ruang hampa. Alam bagi Iqbal merupakan satu struktur dan peristiwa atau suatu cara tingkah laku yang sistematis dan organis dari Diri Mutlak (Ego Absolut). Alam juga pun menggambarkan tabiat terhadap diri manusia sebagai kegiatan kreatif Tuhan. ${ }^{31}$ Bagi Iqbal Alam harus dipahami sebagai suatu organisme yang selalu tumbuh tidak mempunyai batas-batas yang berkesudahan, kecuali adanya

\footnotetext{
${ }^{30}$ Iqbal, The Reconstruction..., h. 126-133.

${ }^{31}$ M. Iqbal, Pesan dari Timur, terj. Abdul Hadi WM (Bandung: Pustaka, 1996), h. 66 .
} 
imanensi yang menjiwai dan yang memelihara keseluruhan tersebut dengan cara evolusi yang digambarkan sebagai suatu gerak menanjak yang teratur dari individu yang paling sederhana, yaitu kepribadian manusia menuju pada realitas Absolut (Ego Mutlak), yaitu Tuhan. ${ }^{32}$

Dengan demikian, bagi Iqbal alam semesta bukan sebagai suatu produk yang sudah selesai dan lengkap, tetapi sedang berada dalam tahap-tahap penyempurnaan. Penciptaan alam bukanlah penciptaan yang final. Menurut Iqbal penciptaan adalah sebuah proses yang berkelanjutan, sedang manusia berada di dalam turut ambil bagian dalam proses tersebut, sehingga akan selalu berproses dengan menciptakan situasi-situasi dan produk-produk baru. Alam semesta sebagai kumpulan ego-ego menurut Iqbal merupakan wadah keinginan-keinginan untukselalu melakukan perubahan-perubahan yang baru dalam kehidupan ini. Alam semesta sesungguhnya selalu berada dalam becoming (menjadi). Ini disebabkan adanya aktivitas ego-ego yang berkelanjutan dalam alam, sehingga kehidupan dalam alam selalu merupakan suatu perjalanan tanpa akhir. ${ }^{33}$

Alam seperti yang kita lihat menurut Iqbal bukan benda materi murni yang menempati ruang hampa. Alam semesta merupakan struktur-struktur peristiwa, model perilaku yang sistematis dan bersifat organis. Alam merupakan perilaku Diri Tuhan (Ego Absolut) seperti halnya karakter untuk ego manusia. Disinilah Iqbal membandingkan watak ego manusia dengan watak alam. Keteraturan alam ini merupakan perilaku Allah, demikianlah gambaran al-Qur'an, sebagaimana dikutip Iqbal. ${ }^{34}$

Dari titik pandang manusia, menurut Iqbal alam merupakan interpretasi dari segala peristiwa, sehingga banyak ilmu yang dapat kita dapatkan dalam merenunginya. Ini karena menurut Iqbal, alam semesta merupakan sumber pengetahuan yang penting, sehingga harus diteliti. Alam semesta bukanlah hasil dari pekerjaan biasa yang sia-sia, tetapi pekerjaan yang mempunyai tujuan (teleologis) Tuhan. Karena itu, alam merupakan salah satu realitas ultim yang harus kita renungkan. Adanya maksud dan tujuan penciptaan

\footnotetext{
${ }^{32}$ Miss Luce dan Claude Maitre, Pengantar..., h. 71.

${ }^{33}$ Iqbal, Metafisika Persia..., h. 20.

${ }^{34}$ Iqbal, Reconstruction ..., h. 56-57.
} 
alam semesta ini merupakan dimensi spiritual bahwa keseluruhan realitas kembali pada Ego Mutlak. ${ }^{35}$

Perdebatan antara panenteisme dengan paham ketuhanan lainnya, sesungguhnya terletak pada pemahaman imanensi maupun transendensi Tuhan. Imanensi Tuhan adalah kehadiran Tuhan dalam diri setiap manusia, setiap makluk hidup, dan dalam alam semesta. Gambaran tentang Tuhan ini membuat alam semesta menjadi tempat memantulkan kemahakuasaan dan penyingkapan kekayaan rahmat Tuhan. Setiap manusia adalah unik dan dalam keunikan tersebut Tuhan hadir. Setiap usaha mencari dan menjumpai Tuhan adalah usaha untuk mewujdukan diri secara sempurna. Karena keberadaan Tuhan pada dasarnya adalah unik sesuai dengan kodrat manusia, maka perwujudan diri manusia itu tidak lain adalah menemukan kesadaran akan keunikan dan kekhasan diri. ${ }^{36}$

Transenden adalah apa yang seluruhnya berbeda dari 'adaada' yang lain. Perbedaanya terletak pada 'adanya' sendiri dan pada apa yang dalam dirinya merupakan hal yang paling intim dan paling radikal. Yang transenden itu mengatasi dunia sampai memiliki suatu eksistensi yang sama sekali lain. Gagasan ini jelas menegaskan bahwa setiap usaha manusia dan dunia harus berakhir dengan membiarkan Tuhan sendiri yang melanjutkan usaha tersebut sampai pada kesempurnaan yang infinitum. Dengan demikian, keilahian dunia dan usaha manusia harus dibawa melalui tindakan dan penyerahan diri secara penuh kepada Tuhan untuk kesempurnaan yang lebih besar dan utuh. ${ }^{37}$

Berdasarkan pada pemahaman imanensi dan transendensi Tuhan, maka imanensi dan transendensi Tuhan dalam dunia selalu berjalan bersamaan. Tuhan bersifat baik transenden maupun imanen terhadap dunia. Mengapa yang Ilahi itu imanen dan bukan tergantung hanya transenden terhadap dunia? Karena dunia sebagai

${ }^{35}$ Ibid.

${ }^{36}$ Frankenberry, Nancy, “Classical Teisme, Panenteisme, and Panteisme: On the Relation between God Construction and Gender and Construction”, Zygon, 28, 1993, h. 29-46.

${ }^{37}$ Cooper, John W., Panenteisme The Other God of the Philosophers: From Plato to the Present, Grand Rapids, MI: Baker Academic, 2006 , h. 322-338. 
realitas tidak mutlak seluruhnya tergantung dari, atau berdasarkan pada Yang Mutlak. Jadi unsur apa pun dalam dunia hanya bisa ada karena ada yang Ilahi yang menunjangnya.

Kesatuan antara keduanya, yang imanen dan transenden. Tuhan itu di manapun tidak dapat ditemukan sebagai salah satu objek atau unsur, akan tetapi di manapun ia dapat ditemukan sebagai dasarnya. Di dalam dunia kita tidak dapat mencari atau menemukan Tuhan sebagai satu objek yang lain. Di manapun kita mencarinya kita tidak akan menemukannya. Tetapi apabila kita mencari syaratsyarat kemungkinan kita berada dan beraktivitas dalam dunia, kita dapat menyadari atau merasakan kehadiran Tuhan di mana-mana. Kita dapat menemukan Tuhan dalam segala-galanya. ${ }^{38}$

Menurut penulis, paham Tuhan bukanlah seperti yang ada dalam bentuk panteisme. Sebab dalam panteisme Tuhan bersemayam dalam segala-galanya. Alam raya dipenuhi dengan Yang Ilahi dengan semua kekuatan-Nya. Panteisme menekankan kepekaan yang tinggi terhadap kehadiran Yang Ilahi dalam dunia. Ia sangat menegaskan imanensi Yang Ilahi. Demikian juga saya tidak menekankan paham Tuhan seperti dalam Deisme, yang melulu menekankan transendensi ilahi. Tuhan yang terpisah dari dunia, yang sedemikian jauh dari manusia dan alam semesta, sehingga Ia tidak mencampur peristiwa-peristiwa dunia ini. Tuhan yang menentukan hukum-hukum alam, yang memadai untuk mengatur peredaran dunia sesuai dengan apa yang ditentukan semenjak dunia ini diciptakan-Nya. ${ }^{39}$

Filsafat ketuhanan (teologi naturalis) Iqbal berbeda dengan filsafat ketuhanan kontemplatif karena Iqbal berangkat dari filsafat manusia yang menekankan pengetahuan langsung tentang keberadaan ego/diri yang bebas - kreatif. Aktivitas kreatif ego menurut Iqbal membebaskan manusia dari segala bentuk determinisme: hukum kausal mekanistik, hukum kausal evolusionistik maupun takdir. Konsep takdir sebagaimana dipahami agama-agama monoteis menampilkan Tuhan sebagai sosok pencipta

${ }^{38}$ Griffin, David Ray, "Panenteisme: A Postmodern Revelation", in In Whom We Live and Move and Have Our Being, P. Clayton and A. Peacocke (eds.), (Grand Rapids, MI: William B. Eerdmans, 2004), h. 36-47.

${ }^{39} \mathrm{Ibid}$, h. 65-67. 
- transenden yang menetapkan tujuan bagi seluruh ciptaannya.

Analogi seperti itu ditolak oleh Iqbal karena pemahaman Tuhan antropomorfisme tersebut jelas tidak compatible dengan pemahaman Iqbal tentang ego sebagai kehendak kreatif. Namun, Iqbal juga tidak sampai terjebak pada paham panteisme yang menekankan imanensi Tuhan (segala sesuatu adalah Tuhan) dan berdasarkan hal itu menafikan kekongkretan ego manusia. Iqbal menolak panteisme dengan mengatakan bahwa Tuhan yang disingkap melalui intuisi adalah suatu person atau ego. Ia adalah sosok transenden yang merespon panggilan kita dan tidak buta atas perasaan dan pemikiran kita. Iqbal juga menolak panteisme berdasarkan fakta bahwa pengetahuan kita tentang realitas ultim (Tuhan) - seperti telah disebutkan sebelumnya - tidak melenyapkan ego yang mengetahui ke dalam yang diketahui (knower and the knower become one).

Gagasan Iqbal tentang hubungan manusia dengan Tuhan merupakan alternatif terhadap imanensi dalam konsep panteisme yang melenyapkan ego manusia maupun transendensi antropomorfisme yang menekankan kemahakuasaan Tuhan atas ciptaanNya. ${ }^{40}$ Iqbal menekankan transendensi Tuhan dalam artiyang berlawanan dengan apa yang dipahami teolog antropomorfisme yaitu Tuhan pencipta yang menguasai dan menentukan segala halihwal ciptaannya. Tuhan bukan pencipta seperti halnya pencipta sepatu yang telah memiliki model, blueprint, gagasan di benaknya untuk dipaksakan pada obyek pasif.

Tuhan menurut Iqbal mencipta secara tak terbatas dan kreatif terus menerus dimana posisi manusia bukanlah boneka pasif bagi kehendak Tuhan melainkan co creator yang aktif berpartisipasi dalam penciptaan kreatif Tuhan. ${ }^{41}$ Proses penciptaan oleh Tuhan menurut

${ }^{40}$ Bandingkan dengan Aquinas yang mengatakan bahwa Tuhan tidak univok (sama sekali sama) maupun equivok (sama sekali lain) dengan manusia melainkan analog yang artinya manusia berbagi Ada Tuhan dalam derajat tertentu atau kalau mau dikongkritkan : manusia berbagi sifat Tuhan namun dalam gradasi (lebih baik, lumayan, kurang baik) yang tak bisa diatributkan kepada kemutlakan Tuhan. lihat Samuel Enoch Stumpf, Socrates to Sartre: A History of Philosophy, (New York : Mc Graw-Hill, 1982), h. 178.

${ }^{41}$ Lihat Majid Fakhry, A History of Islamic Philosophy, (New York: Columbia University Press, 1983), h. 351. 
Iqbal bukan seperti proses penciptaan sepatu yang kreativitasnya berada pada level paling rendah. Proses penciptaan oleh Tuhan dapat diasosiasikan dengan creative genius seorang komposer atau penyair. Manusia sebagai co creator pilihan Tuhan berbagi creative genius Tuhan untuk direalisasikan dalam dunia atau sederhananya: manusia diberkahi Tuhan kebebasan untuk dapat berpartisipasi aktif dalam proses kreatif penciptaanNya. Berangkat dari pemahaman Iqbal ini, maka Iqbal merupakan pengikut dari panenteisme atau teologi proses. Karena itu, relevan sekali Hartshorne dan William Reese memasukkan Iqbal sebagai panenteis Muslim. ${ }^{42}$

Penulis meyakini bahwa Tuhan sungguh-sungguh lebih bersifat panenteistik. Panenteisme lebih menegaskan segala sesuatu ada dalam Tuhan. Tuhan begitu meresapi jagat raya sehingga segala sesuatuberada dalam Tuhan.Berdasarkanimanensidan transendensi Tuhan ini, semakin menampakkan ada kita bahwa secara realitas Tuhan yang menurut hakikatnya melampaui dunia, juga berada $d i$ dalam dunia, Ia imanen di dalam dunia sebagai inti yang menopang segala sesuatu. Artinya, Tuhan dipandang sebagai kedalaman eksistensinya. Kedalaman eksistensi disini, yakni memahami Tuhan dengan berpijak pada kehidupan itu sendiri. Sebuah permenungan yang mendalam atas dimensi kehidupan manusia. Dengan demikian bagi Tuhan adalah imanen juga transenden. Tuhan sekaligus $d i$ dalam dan di atas. Mengenai imanensi dapat dikatakan bahwa Tuhan adalah dasar kreatif permanen dari dunia dan transendensi Tuhan menunjuk pada ‘jurang' yang memisahkan yang tak terbatas dan terbatas. $^{43}$

\section{Penutup}

Berangkat dari pandangan di atas, pemikiran Iqbal tentang alam memberikan arti spiritual baru bagi ilmu pengetahuan fisika, sebagai ilmu pengetahuan alam yang berdimensi spiritual, yaitu sebagai ilmu pengetahuan tentang tata perilaku Tuhan, sehingga setiap penelitian dan permenungan tentang alam sebagai upaya

${ }^{42}$ Charles Hartshorne dan William Reese, Philosophers speak of God..., h. 295.

${ }^{43}$ Gregersen, Niels Henrik, "Three Varieties of Panenteisme”, in In Whom We Live and Move and Have Our Being: Panenteistik Reflections on God's Presence in a Scientific World, P. Clayton and A. Peacocke (eds.), Grand Rapids, MI: William B. Eerdmans, pp. 19-35. 
mengenal dan memahami Ego Mutlak. Disinilah Iqbal mencoba melakukan sintesa filosofis-sufistik mengenai alam antara ilmu pengetahuan alam modern dengan nilai-nilai sufistik yang merujuk pada al-Qur'an sebagai salah satu Sumber Ilmu pengetahuan disamping Alam dan diri, kata Mohammad Iqbal. Oleh karena itu, Iqbal memandang alam semesta dalam perspektif natural sufistik, yaitu bahwa alam semesta merupakan realisasi ego Mutlak untuk memperkenalkan diriNya, sehingga tidaklah salah jika dikatakan al-Qur'an bahwa alam semesta merupakan tata laku Allah. ${ }^{44}$

Alam semesta yang tampak bagi kita sebagai kumpulan dari segala-sesuatu, sesunguhnya menurut Iqbal segala-sesuatu itu bukanlah benda, melainkan suatu tindakan. Hal ini bagi berkaitan dengan alam semesta sebagai pusat kehidupan makhluk hidup. Kehidupan dalam alam semesta menurut Iqbal hanyalah rangkaian tindakan-tindakan. ${ }^{45}$ Disinilah orisinilitas konsep kosmologi metafisik Iqbal dalam paradigma ontologisnya berkaitan dengan tindakan-tindakan, termasuk didalamnya bahwa alam semesta diciptakan tidaklah dengan sia-sia. Semua ini untuk kepentingan manusia sebagai co Creator melalui tindakan-tindakannya yang bermakna.

Filsafat ketuhanan (teologi naturalis) Iqbal berbeda dengan filsafat ketuhanan kontemplatif karena Iqbal berangkat dari filsafat manusia yang menekankan pengetahuan langsung tentang keberadaan ego yang bebas-kreatif. Aktivitas kreatif ego menurut Iqbal membebaskan manusia dari segala bentuk determinisme: hukum kausal mekanistik, hukum kausal evolusionistik maupun takdir. Konsep takdir sebagaimana dipahami agama-agama monoteis menampilkan Tuhan sebagai sosok pencipta - transenden yang menetapkan tujuan bagi seluruh ciptaannya.

Analogi seperti itu ditolak oleh Iqbal karena pemahaman Tuhan antropomorfisme tersebut jelas tidak compatible dengan pemahaman Iqbal tentang ego sebagai kehendak kreatif. Namun, Iqbal juga tidak sampai terjebak pada paham panteisme yang menekankan imanensi Tuhan (segala sesuatu adalah Tuhan) dan berdasarkan hal itu menafikan kekongkretan ego manusia. Iqbal

\footnotetext{
${ }^{44}$ Ibid, h. 57 dan 127

${ }^{45}$ Ibid, h. 51-52
} 
menolak panteisme dengan mengatakan bahwa Tuhan yang disingkap melalui intuisi adalah suatu person atau ego. Ia adalah sosok transenden yang merespon panggilan kita dan tidak buta atas perasaan dan pemikiran kita. Iqbal juga menolak panteisme berdasarkan fakta bahwa pengetahuan kita tentang realitas ultim (Tuhan) - seperti telah disebutkan sebelumnya - tidak melenyapkan ego yang mengetahui ke dalam yang diketahui (knower and the knower become one).

Gagasan Iqbal tentang hubungan manusia dengan Tuhan merupakan alternatif terhadap imanensi dalam konsep panteisme yang melenyapkan ego manusia maupun transendensi antropomorfisme yang menekankan kemahakuasaan Tuhan atas ciptaanNya. ${ }^{46}$ Iqbal menekankan transendensi Tuhan dalam artiyang berlawanan dengan apa yang dipahami teolog antropomorfisme yaitu Tuhan pencipta yang menguasai dan menentukan segala halihwal ciptaannya. Tuhan bukan pencipta seperti halnya pencipta sepatu yang telah memiliki model, blueprint, gagasan di benaknya untuk dipaksakan pada obyek pasif.

Tuhan menurut Iqbal mencipta secara tak terbatas dan kreatif terus menerus dimana posisi manusia bukanlah boneka pasif bagi kehendak Tuhan melainkan co creatoryang aktif berpartisipasi dalam penciptaan kreatif Tuhan. ${ }^{47}$ Proses penciptaan oleh Tuhan menurut Iqbal bukan seperti proses penciptaan sepatu yang kreativitasnya berada pada level paling rendah. Proses penciptaan oleh Tuhan

${ }^{46}$ Bandingkan dengan Aquinas yang mengatakan bahwa Tuhan tidak univok (sama sekali sama) maupun equivok (sama sekali lain) dengan manusia melainkan analog yang artinya manusia berbagi Ada Tuhan dalam derajat tertentu atau kalau mau dikongkritkan : manusia berbagi sifat Tuhan namun dalam gradasi (lebih baik, lumayan, kurang baik) yang tak bisa diatributkan kepada kemutlakan Tuhan. lihat Samuel Enoch Stumpf, Socrates to Sartre: A History of Philosophy, (New York : Mc Graw-Hill, 1982), h. 178

${ }^{47}$ The concept of the concrete world embodied in the Koran is essentially one of a created reality in which the actual and the ideal merge and intertwine and which exhibits a distinct rational pattern. But it is not, for that reason, a 'block universe' or finished product which God has completed, but rather a universe that continually realizes itself across the vast expanses of space and time. Man, as the most dynamic force in this universe, is the principal agent, or coworker with God, in the process of realizing the infinite potentialities of reality. Lihat Majid Fakhry, A History of Islamic Philosophy, (New York : Columbia University Press, 1983), h. 351 
dapat diasosiasikan dengan creative genius seorang komposer atau penyair. Manusia sebagai co creator pilihan Tuhan berbagi creative genius Tuhan untuk direalisasikan dalam dunia atau sederhananya: manusia diberkahi Tuhan kebebasan untuk dapatberpartisipasi aktif dalam proses kreatif penciptaanNya. Berangkat dari pemahaman Iqbal ini, maka Iqbal merupakan pengikut dari panenteisme atau teologi proses. Karena itu, relevan sekali Hartshorne dan William Reese memasukkan Iqbal sebagai panenteis Muslim. ${ }^{48}$

Penulis meyakini bahwa Tuhan sungguh-sungguh lebih bersifat panenteistik. Panenteisme lebih menegaskan segala sesuatu ada dalam Tuhan. Tuhan begitu meresapi jagat raya sehingga segala sesuatu berada dalam Tuhan.Berdasarkanimanensidan transendensi Tuhan ini, semakin menampakkan ada kita bahwa secara realitas Tuhan yang menurut hakikatnya melampaui dunia, juga berada di dalam dunia, Ia imanen di dalam dunia sebagai inti yang menopang segala sesuatu. Artinya, Tuhan dipandang sebagai kedalaman eksistensinya. Kedalaman eksistensi disini, yakni memahami Tuhan dengan berpijak pada kehidupan itu sendiri. Sebuah permenungan yang mendalam atas dimensi kehidupan manusia. Dengan demikian bagi Tuhan adalah imanen juga transenden. Tuhan sekaligus di dalam dan di atas. Mengenai imanensi dapat dikatakan bahwa Tuhan adalah dasar kreatif permanen dari dunia dan transendensi Tuhan menunjuk pada 'jurang' yang memisahkan yang tak terbatas dan terbatas. ${ }^{49}$

\section{Daftar pustaka}

Audah, Ali, Muhammad Iqbal, Sebuah Pengantar dalam Muhammad Iqbal, Membangun Kembali Pikiran Agama Dalam Islam, terj. Ali Audah, Jakarta: Tintamas,1982.

Al-Biruni, Maker's of Pakistan and Modern Muslim India, (Lahore: Kasymir Bazar, 1950.

${ }^{48}$ Charles Hartshorne dan William Reese, Philosophers speak of God, h, 295

${ }^{49}$ Gregersen, Niels Henrik, "Three Varieties of Panenteisme", in In Whom We Live and Move and Have Our Being: Panenteistik Reflections on God's Presence in a Scientific World, P. Clayton and A. Peacocke (eds.), Grand Rapids, MI: William B. Eerdmans, pp. 19-35. 
Cooper, John W., Panenteisme The Other God of the Philosophers: From Plato to the Present, Grand Rapids, MI: Baker Academic, 2006.

Danusuri, Epistimologi Dalam Tasawuf Iqbal, Yogyakarta: Pustaka Pelajar, 1996.

Enver, Ishrat Hasan, Metaphisics of Iqbal, Lahore: Ashraf Press, 1963.

Fakhry, Majid, A History of Islamic Philosophy, New York: Columbia University Press, 1983.

Frankenberry, Nancy, “Classical Teisme, Panenteisme, and Panteisme: On the Relation between God Construction and Gender and Construction”, Zygon, 1993.

Gregersen, Niels Henrik, "Three Varieties of Panenteisme", in In Whom We Live and Move and Have Our Being: Panenteistik Reflections on God's Presence in a Scientific World, P. Clayton and A. Peacocke (eds.), Grand Rapids, MI: William B. Eerdmans.

Griffin, David Ray, “Panenteisme: A Postmodern Revelation”, 2004.

Hartshorne, Charles dan Reese, William, Philosophers speak of God, Chicago-London : The University of Chicago Press, 1976.

in In Whom We Live and Move and Have Our Being, P. Clayton and A. Peacocke (eds.), Grand Rapids, MI: William B. Eerdmans.

Iqbal, Mc. Taggart's Philosophy, dalam Journal of the East India Society, Lahore, 1917.

, The Recontruction of Religious Thought in Islam, New Delhi: Kitab Bhavan, 1981.

M., Pesan dari Timur, terj. Abdul Hadi WM, Bandung: Pustaka, 1996.

, Muhammad, Metafisika Persia: Suatu Sumbangan untuk Sejarah Filsafat Islam, terj. Joebar Ayoeb, Bandung: Mizan, 1995.

Schimel, Gabriel's Wing: A Study into Religion of Sir Muhammad Iqbal, Leiden : E.L. Brill, 1963.

Sharif, M.M., History of Muslim Philosophy, Pakistan: Pakistan Philosophical Congress, 1983.

Smith, Wilfred Contwell, Modern Islam in India, A Social Analysis, Usha Publication, New Delhi, 1979.

Stumpf, Samuel Enoch, Socrates to Sartre: A History of Philosophy, New York : Mc Graw-Hill, 1982. 
Vahiduddin, Syed, Islam in India: Studies and Commentaris, Vol 3 New Delhi: Chanakya Publition, tt.

Whittemore, Robert C., "Hegel As Panenteis”, Studies in Hegel, Series: Tulane Studies in Philosophy, Volume 9, 1960.

, "The meeting of East and West in neglected Vedanta", Dialogue \& Alliance, 1988.

Workman (ed.), John Rowe, Encyclopedia Americana, 2 Encyclopedia Americana Coorporation, 1978. 
Suhermanto Ja'far

halaman ini bukan sengaja dikosongkan 